\title{
ANALISIS ARUS KAS DALAM MENENTUKAN TINGKAT LIKUIDITAS PERUSAHAAN(Studi Kasus pada Koperasi Jasa Keuangan Syariah (KJKS) MAWAR Karanggeneng, Kabupaten Lamongan Periode Januari - Oktober 2013)
}

\author{
N urvita D iah Rahayu \\ Mahasiswa Alumni FEBI UIN SA Surabaya | diahrahayuNUR@ gmail.com
}

\begin{abstract}
Abstrak: Penelitian ini ditujukan untuk menjawab rumusan masalah, bagaimana arus kas dari aktivitas operasi, aktivitas investasi, dan aktivitas pendanaan pada KJKS MAW AR, Karanggeneng Kabupaten Lamongan; Bagaimana tingkat likuiditas perusahaan pada KJKS M AW AR, Karanggeneng Kabupaten Lamongan; Bagaimana analisa arus kas dalam menentukan tingkat likuiditas perusahaan pada KJKS MAWAR, Karanggeneng Kabupaten Lamongan. Teknik pegumpulan data dilakukan dengan cara observasi, wawancara, dan dokumentasi. Sedangkan untuk analisis data menggunakan teknik analisis deskriptif verifikatif. U ntuk mengetahui tingkat likuiditas suatu perusahaan dapat dihitung dengan menggunakan rasio likuiditas, dalam penelitian ini menggunakan rasio lancar (current ratio) dan rasio kas (cash ratio). Hasil penelitian menunjukan bahwa tingkat likuiditas KJKS MAWAR terlalu tinggi, ditunjukkan dengan tingkat current ratio diatas $100 \%$, sehingga banyak dana yang menganggur. Tingkat cash ratio lebih dari 2: 1 hal ini menunjukkan bahwa KJKS MAW AR mampu memenuhi kewajiban jangka pendeknya dengan menggunakan kas yang ada. Dapat disarankan kepada KJKS MAWAR untuk dapat lebih memanfaatkan atau memaksimalkan penggunaan dana yang dimiliki ke sektor lain seperti investasi ke perusaahaan yang sesuai dengan prinsip-prinsip syariah.
\end{abstract}

Kata kunci: Arus kas operasi, investasi, pendanaan, likuiditas

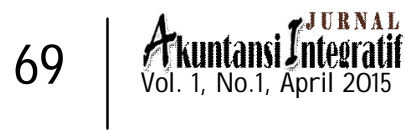




\section{Pendahuluan}

Kehadiran lembaga keuangan syariah baik bank maupun non bank di tengah-tengah lembaga keuangan konvensional memberikan penawaran bagi masyarakat muslim yang membutuhkan jasa keuangan tanpa harus melanggar riba. Dari segi legalitas koperasi syariah memang belum tercantum dalam Undang-Undang Nomor 17 Tahun 2012 tentang perkoperasian. Untuk sementara keberadaan koperasi syariah saat ini didasarkan pada Keputusan Menteri (Kepmen) Koperasi dan UKM Republik Indonesia Nomor 91/Kep M.KUKM/X/2004 pada tanggal 10 September 2004 tentang Petunjuk Pelaksanaan Kegiatan Usaha Koperasi Jasa Keuangan Syariah dan Unit Jasa Keuangan Syariah (KJKS dan UJKS). Setelah itu diterbitkan instrumen Nomor 35.2 Tahun 2007 tentang pedoman SOM (standart operasi manajemen) koperasi jasa keuangan syariah dan unit jasa keuangan syariah (KJKS dan UJKS), instrument Nomor 35.3 pedoman penilaian kesehatan KJKS/JJKS, dan pedoman pengawasan KJKS/UJKS Koperasi. ${ }^{1}$ Dalam SOM KJKS dan UJKS disebutkan bahwa, "KJKS dan UJKS Koperasi harus dapat memperkirakan besarnya pengeluaran dalam setiap hari, minggu atau bulan, sehingga likuiditas minimum dapat ditetapkan secara lebih tepat. Kesemuanya itu perlu didukung oleh pencatatan-pencatatan yang akurat, teliti, rapi dan sistematis."2 Dengan adanya peraturanperaturan tersebut semakin meningkatkan kepercayaan masyarakat pada koperasi syariah.

${ }^{1}$ lbid.

${ }^{2}$ Menteri N egara Koperasi dan U M KM, Standar Operasional M anajemen, 65.

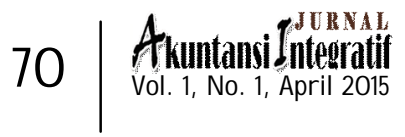


Selain itu, Dewan Standar Akuntansi Keuangan (DSAK) dengan mendapat review dan persetujuan dari Dewan Syariah Nasional Majelis Ulama Indonesia (DSN MUI) telah menerbitkan beberapa pernyataan standar akuntansi keuangan yang berlaku khusus bagi entitas syariah (PSAK syariah). Salah satu hasil pernyataan yang diterbitkan adalah Kerangka Dasar Penyusunan dan Penyajian Laporan Keuangan (KDPPLK) Syariah yang disahkan pada tanggal 27 Juni 2007. KDPPLK Syariah ini diharapkan menjadi acuan bagi penyusun standar akuntansi keuangan syariah, penyusun laporan keuangan, auditor, dan para pengguna lain yang berkepentingan terhadap laporan keuangan. KDPPLK Syariah membahas topik utama, antara lain Paradigma transaksi syariah, Asas transaksi syariah, dan Karakteristik transaksi syariah. ${ }^{3}$ Menurut KDPPLK Syariah, transaksi syariah berasaskan pada lima asas atau prinsip yaitu, persaudaraan (ukhuwah), keadilan ('ada>lah), kemaslahatan (maslahah), keseimbangan (tawa>zun), dan universalisme (syumu>liyah). ${ }^{4}$ Karena pada dasarnya keberadaan koperasi syariah menganjurkan untuk saling tolong menolong dalam kebaikan antar sesama anggota untuk meningkatkan kesejahteraan bersama, sesuai dengan surah al-Ma>idah ayat 2:

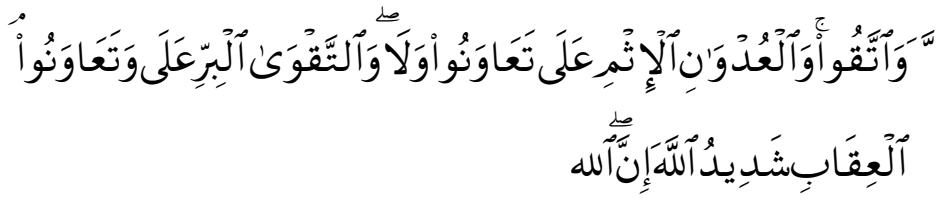

\footnotetext{
${ }^{3}$ Sony W arsono dan Jufri. Akuntansi Transaksi Syariah Akad Jual Beli di LembagaBukan Bank, (Yogyakarta: Asgard Chapter, 2011), 31.

${ }^{4}$ bid, 34.
}

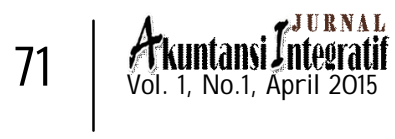


Artinya: “..... dan tolong-menolonglah kamu dalam (mengerjakan) kebajikan dan takwa, dan jangan tolong-menolong dalam berbuat dosa dan pelanggaran. Dan bertakwalah kamu kepada Allah, sesungguhnya Allah amat berat siksa-Nya."5 (Q.S alMa>idah : 2)

Dari ayat di atas dapat diketahui bahwa setiap manusia harus saling tolong-menolong dalam berbuat kebaikan, dan hal ini selaras dengan prinsip koperasi yaitu persaudaraan, dalam koperasi juga menganut prinsip semua dari anggota akan kembali untuk Anggota.

Kas merupakan unsur aktiva yang paling lancar atau dengan kata lain kas merupakan modal kerja yang paling likuid, sehingga dengan ketersediaan kas yang cukup maka perusahaan tidak akan kesulitan dalam memenuhi kewajiban yang jatuh tempo. Tetapi hal ini tidak berarti perusahaan harus mempertahankan persediaan kas dalam jumlah yang besar karena semakin besar kas, maka semakin banyak uang yang menganggur. Perusahaan yang mampu menghasilkan kas yang cukup dari aktivitas operasinya kemungkinan besar memiliki kondisi keuangan yang sehat karena tidak tergantung pada sumber pembiayaan dari luar perusahaan. Perusahaan yang memiliki kondisi keuangan yang sehat akan mampu bertahan hidup dan memenuhi kewajiban-kewajiban saat jatuh tempo. Hubungan antara arus kas dengan likuiditas S.Munawir mengemukakan: "Laporan arus kas dapat memberikan informasi yang memungkinkan para

${ }^{5}$ Departemen Agama R.I., al-Qur'an dan Terjemahnya, (Surabaya: CV. Karya U tama, 2000), 157.

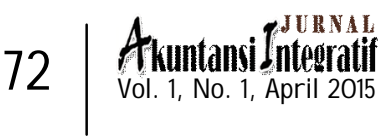


pemakai untuk mengevaluasi perubahan aktiva bersih perusahaan, struktur keuangan (termasuk likuiditas dan solvabilitas), dan kemampuan untuk mempengaruhi jumlah serta waktu arus kas dalam rangka adaptasi dengan perubahan keadaan dan peluang." 6

Pada KJKS MAWAR, dalam kegiatan usahanya selama kurun waktu kurang lebih 8 tahun sempat mengalami defisit dana dan bisa dikatakan hampir bangkrut. Namun dalam setahun terakhir ini, KJKS MAWAR mampu bangkit dari keterpurukannya. ${ }^{7}$ Hal ini dibuktikan dengan semakin meningkatnya rasio Return On Equity (ROE) setiap bulannya, pada akhir bulan September 2013 tercatat sebesar 3,8\% yang sebelumnya pada bulan Januari hanya sebesar 0,5\%. ${ }^{8}$ Untuk pencatatan dan penyajian laporan keuangan KJKS MAWAR menggunakan sistem komputerisasi. Karena keterbatasan sistem masih terdapat beberapa laporan yang tidak sesuai dengan ketentuan Keputusan Menteri Koperasi dan UKM, diantaranya dalam laporan arus kas tidak dibedakan antara arus kas dari aktivitas operasi, aktivitas investasi dan akitivitas pendanaan. Selain itu KJKS MAWAR juga kurang memberanikan diri dalam mengalokasikan dananya kepada sektor lain seperti investasi, sehingga masih banyak dananya yang menganggur.

Koperasi Jasa Keuangan Syariah (KJKS) MAWAR didirikan pada tahun 2008 dengan Tanda Daftar Perusahaan (TDP) Nomor 13.18.2.64.00087 dan mendapat pengesahan dari Bupati Lamongan. Ruang lingkup kegiatan perusahaan terutama meliputi koperasi jasa

\footnotetext{
${ }^{6}$ S. Munawir, Akuntansi Keuangan dan Manajemen, (Yogyakarta: BPFE, 2002). 242.

${ }^{7}$ Taufiqurrahman, W awancara, KJKS M AW AR Karanggeneng, 280 ktober 2013.

${ }^{8}$ Rasio Keuangan KJKS Mawar periode September 2013.
}

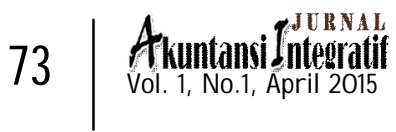


keuangan yang sesuai dengan prinsip syariah. Nama "MAWAR" dipilih karena koperasi tersebut didirikan dibawah naungan Pondok Pesantren Matholi'ul Anwar yang disingkat dengan "MAWAR" yang beralamatkan di Jl.Raya Simo Karanggeneng Kabupaten Lamongan.

Pencataan keuangan dan penyusunan laporan keuangan KJKS MAWAR menggunakan sistem komputerisasi, namun untuk memperoleh data yang lebih akurat, pihak manajemen juga melakukan perhitungan dan penyusunan laporan keuangan secara manual dengan menggunakan bantuan program Ms.Excel. Dalam penyajian laporan arus kas, KJKS MAWAR menggunakan metode langsung (direct method). ${ }^{9}$ Metode langsung digunakan dengan alasan lebih terperinci dan lengkap. Berikut ini data keuangan bulanan dari KJKS MAWAR

\section{Performa Keuangan KJKS MAWAR}

\section{Laporan Arus Kas}

Laporan arus kas KJKS MAWAR, menunjukkan aliran kas masuk dan aliran kas keluar yang terjadi selama satu periode akuntansi. Pelaporan keuangan KJKS MAWAR dilakukan setiap bulan. Metode laporan arus kas yang digunakan adalah metode langsung, sebagaimana yang dianjurkan dalam Peraturan Menteri Negara dan UKM.

\section{Neraca}

Neraca adalah sebuah daftar aset dan kewajiban organisasi pada saat tertentu. Selisih antara aset dan kewajiban disebut modal. Modal dapat dikatakan sebagai aset yang dimiliki oleh pemilik organisasi

${ }^{9}$ Taufiqurrahman, W awancara.

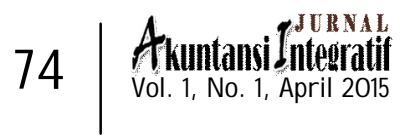


yaitu jumlah yang akan tersisa jika seluruh kewajiban dibayar. ${ }^{10}$

\section{Likuiditas}

Munawir mendefinisikan likuiditas merupakan menunjukkan kemampuan suatu perusahaan untuk memenuhi kewajiban keuangannya yang harus segera dipenuhi, atau kemampuan perusahaan untuk memenuhi kewajiban keuangan pada saat ditagih. ${ }^{11}$ Berdasarkan pendapat diatas, pengertian likuiditas dapat dikatakan merupakan kemampuan perusahaan suatu perusahaan untuk memenuhi atau membayar kewajiban keuangan jangka pendek yang harus segera dipenuhi dengan menggunakan aktiva lancar yang tersedia.

Untuk dapat menilai posisi keuangan jangka pendek (likuiditas) berikut ini rasio yang dapat digunakan sebagai alat untuk menganalisis dan menginterpretasikan data tersebut.

a. Rasio Lancar (Current Ratio)

Current ratio membandingkan antara aktiva lancar dan kewajiban lancar yang menunjukkan sejauh mana aktiva lancar menutupi kewajibankewajiban. Current ratio yang rendah biasanya dianggap menunjukkan terjadinya masalah dalam likuidasi, sebaliknya current ratio yang terlalu tinggi juga kurang bagus karena menunjukkan banyaknya dana menganggur yang pada akhirnya dapat mengurangi kemampulabaan perusahaan. ${ }^{12}$

\footnotetext{
${ }^{10}$ James D.Stice, Earl K.Stice dan Fred Skousen, Akuntansi Keuangan Intermediate accounting, (Jakarta: Salemba Empat, 2009), 120.

${ }^{11}$ Munawir, Akuntansi Keuangan dan Manajemen, 31.

${ }^{12}$ Agnes Sawir, Analisa Kinerja Keuangan dan Perencanaan Keuangan Perusahaan, Jakarta: Gramedia Pustaka U tama, 2001), 10.
} 
b. Rasio Cepat (Quick Ratio)

Rasio ini juga desebut dengan Acid test ratio yang juga digunakan untuk mengukur kemampuan suatu perusahaan dalam memenuhi kewajiban jangka pendeknya. Perhitungannya dengan cara mengurangkan aktiva lancar dengan persediaan.

c. Rasio Kas (Cash Ratio)

Rasio ini merupakan rasio yang menunjukkan posisi kas yang dapat menutupi hutang lancar dengan kata lain cash ratio merupakan rasio yang menggambarkan kemampuan kas yang dimiliki dalam manajemen kewajiban lancar tahun yang bersangkutan. ${ }^{13}$

Karena KJKS MAWAR adalah sebuah lembaga keuangan, jadi untuk menghitung tingkat likuiditas degunakan metode rasio lancar dan rasio kas. Metode Rasio cepat digunakan, karena KJKS MAWAR tidak memiliki persediaan yang dapat dihitung.

\section{Analisis}

Berdasarkan perhitungan laporan arus kas yang dikelompokkan berdasarkan aktivitasnya yaitu aktivitas operasi, investasi dan pendanaandianalisis sebagai berikut:

1. Arus Kas Aktivitas Operasi

Arus kas dari aktivitas operasi terutama diperoleh dari aktivitas penghasil utama pendapatan KJKS atau UJKS Koperasi yang pada umumnya berasal dari transaksi yang mempengaruhi penetapan laba atau

${ }^{13}$ Ibid. 
rugi bersih. ${ }^{14}$ Pada KJKS MAWAR pendapatan utamanya adalah berasal dari pendapatan margin Mura@bah\}ah, pendapatan ujroh Qard, dan Pendapatan ujroh Hiwalah, dan Pendapatan lain-lain. ${ }^{15}$ Perolehan kas bersih dari aktivitas operasi mengalami peningkatan setiap bulannya, kecuali pada bulan Maret dan bulan Agustus. Pada bulan Februari mengalami peningkatan sebesar $234 \%$ atau Rp 3.470.168, pada bulan Maret mengalami penurunan sebesar 21\% atau sebesar (Rp 1.043.572) hal ini disebabkan karena meningkatnya biaya-biaya operasional seperti kenaikan upah karyawan. Pada bulan Agustus terjadi penurunan sebesar 40\% atau (Rp 4.269.463) hal ini disebabkan karena menurunnya pendapatan sedang pengeluaran mengalami peningkatan.

2. Arus Kas Aktivitas Investasi

Aktivitas investasi mencerminkan penerimaan dan pengeluaran kas sehubungan dengan sumber daya yang bertujuan untuk menghasilkan pendapatan dan arus kas masa depan. ${ }^{16}$ Pada KJKS MAWAR perolehan kas dari aktivitas investasi adalah berasal dari instrument keuangan koperasi berupa simpanan pokok, simpanan wajib, simpanan khusus, simapanan Mudja>rabah berjangka, serta angsuran dari pembiayaan yang diberikan kepada anggota.

KJKS MAWAR memiliki berbagai instrument keuangan penghimpun dana anggota yang bisa diolah sebagai pembiayaan terhadap anggota.

\footnotetext{
${ }^{14}$ Peraturan Menteri N egara Koperasi dan UKM, Pedoman Standar Operasional Manajemen Koperasi, 90.

${ }^{15}$ Taufiqurrahman, wawancara.

${ }^{16}$ Peraturan Menteri N egara Koperasi dan U KM, Pedoman SOM Koperasi, 90.
}

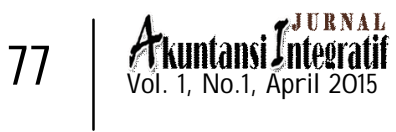


Dimana keuntungan dari aktivitas tersebut kembali lagi untuk anggota yang masuk dalam aktivitas investasi.

3. Arus Kas Aktivitas Pendanaan

Aktivitas pendanaan memprediksi klaim terhadap arus kas masa depan oleh para pemasok modal KJKS atau UJKS Koperasi. ${ }^{17}$ Pada KJKS MAWAR, arus kas aktivitas pendanaan merinci arus kas yang digunakan untuk pendanaan kepada anggota Koperasi, seperti penarikan simpanan umum, simpanan pokok dan simpanan khusus anggota. Sedangkan perolehan dana yang masuk dalam aktivitas pendanaan berasal dari pinjaman pihak tiga atau Bank.

Tingkat Likuiditas KJKS MAWAR bulan Januari -

Oktober 2013

\begin{tabular}{|l|c|c|c|c|}
\hline \multirow{2}{*}{ Bulan } & \multicolumn{4}{|c|}{ Rasio \% } \\
\cline { 2 - 5 } & $\begin{array}{l}\text { Current } \\
\text { Ratio }\end{array}$ & $\begin{array}{l}\text { Naik } \\
\text { (Turun) }\end{array}$ & $\begin{array}{l}\text { Cash } \\
\text { Ratio }\end{array}$ & $\begin{array}{l}\text { Naik } \\
\text { (Turun) }\end{array}$ \\
\hline Januari & 171.67 & - & 23.15 & - \\
\hline Februari & 168.39 & $(1.91)$ & 30.42 & 31.42 \\
\hline Maret & 155.63 & $(7.58)$ & 34.20 & 12.43 \\
\hline April & 153.67 & $(1.26)$ & 24.26 & $(29.06)$ \\
\hline Mei & 150.80 & $(1.86)$ & 22.77 & $(6.15)$ \\
\hline Juni & 148.46 & $(1.55)$ & 20.47 & $(10.08)$ \\
\hline Juli & 140.14 & $(5.60)$ & 15.15 & $(26.02)$ \\
\hline Agustus & 134.42 & $(4.08)$ & 24.31 & 60.49 \\
\hline September & 131.53 & $(2.15)$ & 28.69 & 18.04 \\
\hline Oktober & 130.44 & $(0.83)$ & 31.39 & 9.42 \\
\hline
\end{tabular}

${ }^{17}$ Peraturan Menteri N egara Koperasi dan UKM, 90.

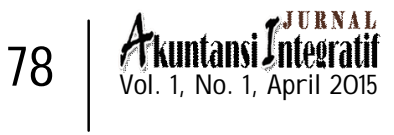


Pada KJKS MAWAR mengalami penurunan dari bulan Januari sampai Oktober, namun tingkat current ratio diatas 100\%.Meskipun tingkat likuiditas dari segi current ratio rata-rata diatas 100\%, hal ini bisa dikatakan kurang bagus, karena dengan demikian terlalu banyak dana yang mengganggur. Seharusnya dengan dana yang banyak bisa digunakan untuk ekspansi atau investas sehingga dana titipan dari anggota dapat terjaga dan lebih berkembang.

Cash ratio menunjukkan kemampuan kas yang dimiliki oleh perusahaan untuk menutupi kewajiban lancar yang dimiliki perusahaan. Pada KJKS MAWAR banyak mengalami peningkatan kecuali pada bulan April, Mei, Juni, dan Juli.

Meskipun cash ratio menunjukkan angka fluktuatif setiap bulannya, tetapi dalam perbandingan antara kas atau aktiva lancar dengan hutang lancarnya masih diatas 2 : 1, sehingga KJKS MAWAR masih dapat menggunakan kasnya untuk memenuhi kewajiban jangka pendeknya atau dapat pula dikatakan likuid.

\section{Arus Kas dan Rasio Likuiditas}

Koperasi Jasa Keuangan Syariah (KJKS) MAWAR

Periode Januari - Oktober 2013

\begin{tabular}{|l|l|l|l|l|c|}
\hline \multirow{2}{*}{ Bulan } & \multicolumn{3}{|c|}{ Arus Kas } & Rasio Likuiditas \% \\
\cline { 2 - 6 } & $\begin{array}{l}\text { Aktivitas } \\
\text { Operasi }\end{array}$ & $\begin{array}{l}\text { Aktivitas } \\
\text { Investasi }\end{array}$ & $\begin{array}{l}\text { Aktivitas } \\
\text { Pendanaan }\end{array}$ & $\begin{array}{l}\text { Current } \\
\text { Ratio }\end{array}$ & $\begin{array}{l}\text { Cash } \\
\text { Ratio }\end{array}$ \\
\hline Januari & $1,484,102$ & $47,396,653$ & $(15,696,563)$ & 171.67 & 23.15 \\
\hline Februari & $4,954,270$ & $147,098,730$ & $(121,715,702)$ & 168.39 & 30.42 \\
\hline Maret & $3,910,698$ & $162,315,749$ & $(119,851,822)$ & 155.63 & 34.20 \\
\hline April & $6,097,217$ & $112,628,800$ & $(156,489,860)$ & 153.67 & 24.26 \\
\hline
\end{tabular}




\begin{tabular}{|l|c|c|c|c|c|} 
Mei & $6,240,947$ & $167,644,641$ & $(172,544,117)$ & 150.80 & 22.77 \\
\hline Juni & $7,634,950$ & $144,930,816$ & $(156,368,897)$ & 148.46 & 20.47 \\
\hline Juli & $10,555,516$ & $(5,163,397)$ & $(13,835,585)$ & 140.14 & 15.15 \\
\hline Agustus & $6,286,053$ & $242,672,255$ & $(152,476,311)$ & 134.42 & 24.31 \\
\hline September & $9,261,357$ & $387,784,207$ & $(330,746,405)$ & 131.53 & 28.69 \\
\hline Oktober & $12,508,938$ & $290,646,328$ & $(257,518,380)$ & 130.44 & 31.39 \\
\hline
\end{tabular}

Berdasarkan tabel di atas, secara keseluruhan laporan arus kas KJKS MAWAR dalam keadaan stabil, karena selama 10 bulan berturut-turut mengalami peningkatan. Hal ini terjadi karena selama kurun waktu10 bulan tersebut aktivitas operasi yang dilakukan perusahaan dapat menambah dana bagi perusahaan untuk dapat memenuhi kewajiban jangka pendeknya. Sementara perolehan dana dari aktivitas investasi juga mengalami peningkatan, kecuali pada bulan juli menurun sebesar Rp 5.163.397, hal ini disebabkan karena meningkatnya jumlah pencairan pembiayaan Mura@bahah, yang diasumsikan dapat memberikan keutungan di masa mendatang. Sementara untuk kas yang digunakan untuk aktivitas pendanaan setiap bulannya cenderung mengalami peningkatan. Peningkatan ini disebabkan karena semakin meningkatnya jumlah penarikan dana yang dilakukan oleh anggota, namun KJKS masih dapat memenuhi kewajiban tersebut dengan dana kas yang dimiliki dan diperoleh dari aktivitas operasi dan investasi.

Tingkat current ratio KJKS MAWAR menunjukkan penurunan setiap bulannya. Meskipun setiap bulannya mengalami penurunan tetapi masih dalam keadaan likuid, hal tersebut disebabkan adanya konsistensi aktiva lancar dalam menutupi hutang 
lancar perusahaan, yaitu semakin meningkatnya permintaan pembiayaan yang dilakukan oleh anggota. Cash ratio mengalami peningkatan setiap bulannya, hal ini dapat diartikan bahwa tertibnya pembayaran yang dilakukan oleh anggota atas pembiayaan yang diberikan, dan dengan demikian perusahaan dapat memenuhi kewajiban lancarnya dengan menggunakan kas yang diproleh dari aktivitas operasi dan pendanaan. Peningkatan tingkat rasio kas dapat disebabkan karena meningkatnya jumlah hutang lancar yang dapat diimbangi dengan peningkatan pula pada jumlah kas yang dimiliki perusahaan.

\section{Kesimpulan}

Dari hasil analisis laporan arus kas dalam menentukan tingkat likuiditas pada Koperasi Jasa Keuangan Syariah (KJKS) MAWAR Karanggeneng Kabupaten Lamongan selama kurun waktu 10 bulan, yaitu pada bulan Januari - Oktober 2013 dapat ditarik kesimpulan sebagai berikut:

1. Setelah dilakukan analisis laporan arus kas yang terdiri dari aktivitas operasi, investasi, dan pendanaan, dapat diketahui penggunaan aliran kas perusahaan selama periode tersebut. Arus kas KJKS MAWAR selama kurun waktu 10 bulan yaitu dari bulan Januari - Oktober 2013 mengalami surplus. Hal ini dapat dilihat dimana kas bersih yang diterima dari aktivitas operasi dan investasi perusahaan dapat mengimbangi penggunaan kas pada aktivitas investasi dan pendanaan.

2. Tingkat likuiditas yang dimiliki Koperasi dinilai terlalu tinggi atau dengan kata lain KJKS MAWAR

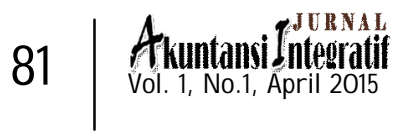


dalam keadaan likuid, namun terlalu tingginya tingkat likuiditas juga menunjukkan bahwa kurangnya pengelolaan dana yang dimiliki sehingga masih banyak dana yang menganggur. Hal ini terlihat dari hasil perhitungan rasio likuiditas, current ratio Koperasi diatas 100\% meskipun setiap bulannya mengalami penurunan, dan dengan menggunakan kas perusahaan KJKS MAWAR dapat memenuhi kewajiban jangka pendeknya.

3. Analisis arus kas dalam menentukan tingkat likuiditas adalah pengukuran tingkat likuiditas suatu perusahaan dengan menggunakan laporan arus kas sebagai sumber datanya yang dihitung melalui perhitungan rasio likuiditas, yaitu rasio lancar (current ratio) dan rasio kas (cash ratio). Setelah dilakukan perhitungan rasio likuiditas dengan menggunakan current ratio yaitu tingkat likuiditasnya diatas 100\%, hal ini disebabkan karena tingkat pendapatan kas dari aktivitas operasi dan investasi terus mengalami peningkatan setiap bulannya, meskipun kewajiban pendek KJKS juga meningkat, dan perusahaan dapat memenuhi kewajiban lancarnya dengan menggunakan kas bersih perusahaan yang bersumber dari aktivitas operasi dan investasi.

\section{Daftar Pustaka}

Agnes Sawir, Analisa Kinerja Keuangan dan Perencanaan Keuangan Perusahaan, Jakarta, Gramedia Pustaka Utama, 2001. 
Bambang Riyanto, Dasar-dasar Pembelanjaan

Perusahaan, Yogyakarta, BPFE UGM, 2001.

Dwi Prastowo dan Rifka Julianty, Analisis Laporan Keuangan, Yogyakarta, UUP AMP YKPN, 2005.s

Henry Simamora. Akuntansi Basis Pengambilan

Keputusan Bisnis Edisi II, Yogyakarta, UPP AMP YKPN, 2002

Kieso E. Donald, Jerry J.Wegant, and Terry D. Warfield, Intermediate Accounting, 11th Edition, Edisi Revisi, Jakarta, Airlangga, 2005.

Lukman Syamsudin, Manajemen Keuangan Perusahaan, Jakarta, Raja Grafindo Persada, 2002.

Martono dan Agus D. Harjito, Manajemen Keuangan,,Yogyakarta, Ekonisia, 2002.

M. Hanafi $M$ dan Abdul Halim, Analisa Laporan Keuangan, Yogyakarta, UUP AMP YKPK, 2005.

M. Ridwan. Manajemen Baitul mal Wa Tamwil, Yogyakarta, UII Pres, 2004

M. Syafi'i Antonio. Bank Syari'ah dan Teori ke Praktek, Jakarta, Gema Insani, 2001

Punaji Setyosari, Metode Penelitian Pendidikan dan Pengembangan, Jakarta, Kencana, 2010.

Slamet Sugiri dan Sumiyana, Akuntansi Keuangan Menengah Buku 1, Yogyakarta, UPP MP YKPN, 1996.

Suharsimi Arikunto, Prosedur Penelitian Suatu

Pendekatan Praktek, Edisi Revisi IV, Jakarta, Rineka Cipta, 2006.

S. Munawir. Analisa Laporan Keuangan, Yogyakarta, Liberty, 2007

-----, Akuntansi Keuangan dan Manajemen,
Yogyakarta, BPFE, 2002

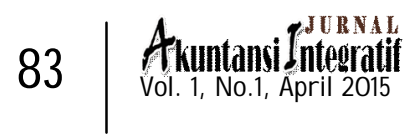


Sofyan Syafri Harahap, Analisis Kritis atas Laporan Keuangan, Jakarta, Rajawali Pers, 2011

Sony Warsono dan Jufri. Akuntansi Transaksi Syariah Akad Jual Beli di Lembaga Bukan Bank, Yogyakarta, Asgard Chapter, 2011

Sugiyono, Memahami Penelitian Kualitatif, Bandung, Alfabeta, 2010

--------, Metode Pnelitian Bisnis, Bandung , Alfabeta, 2008

Sukudin dan Mundir, Metode Penelitian: Menimbang dan

Mengantar Kesuksesan Anda dalam Dunia Penelitian, Surabaya, Insan Cendikia, 2005

Zaki Baridwan, Intermediate Accounting Edisi 8, Yogyakarta, BPFE, 2010.

Ahmad Hanafi, Wawancara, KJKS MAWAR

Karanggeneng, 28 Oktober 2013.

Departemen Agama R.I., Al-Qur'an dan terjemahnya, Surabaya,CV.Karya Utama, 2000.

Ecatarina Febiola Annisa, Pengaruh Arus Kas Operasi Terhadap Likuiditas Pada PT. PLN (Persero)

Distribusi Jawa Barat Dan Banten, Skripsi, Program

Studi Akuntansi, Fakultas Ekonomi, Universitas

Komputer Indonesia, 2007. Dalam http://elib.unikom.ac.id Ikatan Akuntan Indonesia. Pernyataan Standar Akuntansi

Keuangan Nomor 101 Tentang Penyajian Laporan Keuangan Syariah. Jakarta, Dewan Standar Akuntansi Keuangan IAI, 2009

-------, PSAK Nomor 2 Pernyataan Standar Akuntansi Keuangan Laporan Arus Kas, Jakarta: DSAK IAI, 2009.

Kementrian Koperasi dan UKM RI. Koperasi Syariah: Inkopsyah BMT Bukukan Aset Rp158 miliar.

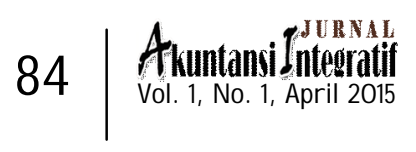


dalamhttp://depkop.go.id/index., Diakses 7 Nopember 2013.

Menteri Negara Koperasi dan UMKM, Peraturan Nomor 35.2/Per/M.KUKM/X/2007 Tentang : Standar Operasional Manajemen Koperasi dan Jasa Keuangan Syariah dan Unit Jasa Keuangan Syariah, 2007.

Muslihin al Hafizh, Pengertian data dan Fakta dalam Penelitian.

Dalam http://referensi_makalah.com/2012/08/pengertian-data-dan-faktadalam.html, diakses pada Nopember 2013.

M. Iqbal Nur, Wawancara, KJKS MAWAR Karanggeneng, 28 Oktober 2013.

Risca Damayanthi, Analisis Laporan Arus Kas untuk Menilai Kinerja Keuangan pada PT.Indocement Perkasa, Tbk., Skripsi, Jurusan Akuntansi, Universitas Gunadarma, 2013. Dalam http://repository.gunadarma.ac.id, Diakses 7 Nopember 2013.

Rasio Keuangan KJKS Mawar periode September 2013.

Taufiqurrahman, Wawancara, KJKS MAWAR Karanggeneng, 28 Oktober 2013. 